\title{
PENGEMBANGAN PEMBELAJARAN INTERAKTIF BERBASIS DISCOVERY LEARNING UNTUK MENINGKATKAN KEMAMPUAN REPRESENTASI MATEMATIS SISWA MAN 1 MEDAN
}

\author{
Maulida Hafni $^{1}$, Edi Syahputra ${ }^{2}$, Nerli Khairani ${ }^{2}$
}

\begin{abstract}
ABSTRAK
Penelitian ini bertujuan untuk: 1) Untuk menemukan pembelajaran interaktif berbasis discovery learning yang valid, praktis dan efektif dalam meningkatkan kemampuan kemampuan representasi matematis dan siswa di MAN 1 Medan; 2) Untuk mendeskripsikan peningkatan kemampuan representasi matematis siswa dengan menggunakan pembelajaran interaktif berbasis discovery learning di MAN 1 Medan. Penelitian ini merupakan penelitian pengembangan yang dilakukan dalam dua tahap, yaitu tahap pertama pengembangan pembelajaran interaktif melalui model pembelajaran discovery learning dengan menggunakan model pengembangan 4-D (define, design, develop, dan disseminate) Thiagarajan dan tahap kedua mengujicobakan pembelajaran interaktif melalui model pembelajaran discovery learning yang dikembangkan. Dari hasil uji coba I dan uji coba II diperoleh: 1) Pembelajaran interaktif berbasis Discovery learning yang dikembangkan di MAN 1 Medan telah memenuhi kriteria valid, praktis dan efektif; 2) Kemampuan representasi matematis siswa MAN 1 Medan dengan pembelajaran interaktif berbasis Discovery learning meningkat, ditinjau dari $\mathrm{N}$-Gain uji coba I sebesar 0,25 pada kategori rendah meningkat menjadi 0,31 pada kategori sedang pada uji coba II.
\end{abstract}

Kata Kunci: pembelajaran interaktif, discovery learning, kemampuan representasi matematis.

\section{PENDAHULUAN}

Dalam dunia pendidikan, sekolah mempunyai peranan penting dalam membekali dan membentuk pengetahuan matematika siwa dimasa depan. Konsep dasar dalam ilmu matematika pun harus dapat ditanamkan dalam benak para siswa. Untuk mencapai hal tersebut, guru sebagai pelaku utama proses pembelajaran di kelas merupakan potensi utama perkembangan pendidikan, sebaiknya guru setiap saat harus mengembangkan potensinya dalam rangka meningkatkan kualitas pembelajaran.

Begitu banyak cara yang bisa ditempuh untuk meningkatkan kualitas pembelajaran, salah satunya adalah pemanfaatan desain pembelajaran. Rahmawati (2016) salah satu hal yang berpengaruh dalam pembelajaran yang efektif adalah desain pembelajaran yang di buat sesuai dengan kebutuhan peserta didik dan dilakukan demi tercapainya tujuan pembelajaran.

Untuk itu guru perlu mengembangkan pembelajaran interaktif. Menurut Wahab (2016):

"Pembelajaran interaktif adalah suatu cara atau teknik pembelajaran yang digunakan guru pada saat menyajikan bahan pelajaran, guru sebagai pemeran utama dalam menciptakan situasi interaktif yang edukatif, yaitu interaksi antara guru dengan siswa, siswa dengan siswa dan dengan sumber pembelajaran dalam menunjang tercapainya tujuan belajar. Pembelajaran interaktif juga merupakan proses pembelajaran

${ }^{1}$ Corresponding Author: Maulida Hafni

MAN 1Medan, Medan, Sumatera Utara, Indonesia

E-mail: lidahafni@gmail.com

${ }^{2}$ Co-Author: Edi Syahputra \& Nerli Khairani Program Studi Pendidikan Matematika Universitas Negeri Medan, Medan, 20221, Indonesia interaksi baik antara guru dan siswa, siswa dengan siswa atau antara siswa dengan lingkungannya. Melalui proses interaksi memungkin kemampuan siswa akan berkembang mental maupun intelektual."

Sejalan dengan hal tersebut, Ali (2014) menyatakan bahwa "pembelajaran interaktif menekankan pada proses diskusi sehingga hasil belajar diperoleh melalui interaksi antara siswa dengan guru, siswa dengan siswa, juga interaksi antara siswa dengan bahan yang dipelajari, serta antara pikiran siswa dengan lingkungan." Patut dingat dan diperhatikan bahwa manusia khususnya siswa dapat menyerap suatu materi /pembelajaran/ ilmu apabila ilmu yang disampaikan dan dikemas dalam bentuk yang menarik dan mengesankan, sehingga pembelajaran yang mereka simak akan terus teringat-ingat di benak mereka.

Menurut England, Elaine and Finney, Andy (2002) mengatakan bahwa" Media Interaktif adalah integrasi dari media digital termasuk kombinasi dari electronic text, graphics, moving images, dan sound, ke dalam lingkungan digital yang terstruktur yang dapat membuat orang berinteraksi dengan data untuk tujuan yang tepat". Berkaitan dengan perkembangan teknologi maka media pembelajaran yang ada juga mengalami perkembangan. Banyak media yang dikembangkan dengan menggunakan bantuan teknologi. Salah satu media yang berkembang dikenal dengan istilah multimedia. Menurut Munadi (2008) bahwa "Multimedia pembelajaran adalah media yang mampu melibatkan banyak indera dan organ tubuh selama proses pembelajaran berlangsung".

Faktanya dilapangan, berdasarkan data BPS (Badan Pusat Statistik, 2018) survei penggunaan dan pemanfaatan teknologi informasi dan

Pengembangan Pembelajaran Interaktif Berbasis Discovery Learning untuk Meningkatkan Kemampuan Representasi Matematis Siswa MAN 1 Medan 
komunikasi di sektor pendidikan ini dilakukan terhadap 4.014 sekolah yang tersebar di 34 provinsi. Berdasarkan jenjang pendidikan, SD dan sederajat sebanyak 64,55 persen, SMP dan sederajat sebanyak 19,22 persen dan SMA dan sederajat sebanyak 16,23 persen. Hal ini menunjukkan penggunaan multimedia sebagai sarana pembelajaran jarang digunakan.

Kemudian berdasarkan hasil observasi yang dilakukan di MAN 1 Medan ternyata sekolah tersebut memiliki fasilitas-fasilitas yang mendukung untuk mengembangkan multimedia pembelajaran. Misalnya komputer, lab computer tersendiri, setiap kelas memiliki akses untuk belajar menggunakan media dan sebagainya. Namun berdasarkan wawancara langsung terhadap kepala sekolah ternyata sekitar $80 \%$ pengajar belum memanfaatkan fasilitas-fasilitas yang tersedia disekolah tersebut. Kemudian tahap selanjutnya dilakukan survey pada beberapa kelas X yang dipilih secara acak, ternyata terdapat fakta menarik bahwa $73 \%$ dari siswa kelas $\mathrm{X}$ menjawab matematika sulit dimengerti dan susah rumusnya. Padahal saat di interview, siswa menjawab matematika bukan pelajaran sulit. Selain itu $38 \%$ dari mereka pun menjawab bahwa buku paket yang mereka punya tidak menarik untuk dipelajari. Buku matematika yang di gunakan siswa saat ini menggunakan cara penyampaian dengan bercerita panjang lebar kemudian siswa di berikan soal yang banyak. Dengan begitu siswa akan jenuh belajar dan tidak memahami penjelasan dan soal sehingga akhirnya siswa kesulitan untuk menjawab soal-soal tersebut.

Representasi matematika yang merupakan salah satu kompetensi adalah suatu aspek yang selalu hadir dalam pembelajaran matematika. Kemampuan representasi adlah suatu kemampuan matematika dengan pengungkapan ide-ide matematika (masalah, pernyataan, definisi, dan lain-lain) dalam berbagai cara (Syafri, 54: 2017). Representasi atau model dari suatu situasi atau konsep matematika jika disajikan dalam bentuk yang sudah jadi sesungguhnya dapat dipandang telah mengurangkan atau meniadakan kesempatan bagi siswa untuk berpikir kreatif dan menemukan sejak awal konsep matematika yang terkandung dalam suatu situasi masalah.

Mustangin (2015) menyatakan bahwa ragam representasi yang sering digunakan dalam mengkomunikasikan matematika antara berupa sajian visual seperti tabel, gambar, grafik; pernyataan matematika atau notasi matematika; dan teks tertulis yang ditulis daengan bahasa sendiri baik formal maupun informal, ataupun kombinasi semuanya. Pembelajaran matematika dikelas sebaiknya memberikan kesempatan yang cukup bagi siswa untuk melatih dan mengembangkan kemampuan representasi matematis (Sabirin, 2014). Pada hasil penelitian yang diungkapkan oleh Zazkis dan Liljedahl (2004) serta Gagtis dan Elia (2004) yang memperlihatkan bahwa kemampuan pemahaman dan reprsentasi siswa yang cerdas merupakan kunci untuk mendapatkan solusi memecahkan masalah yang tepat.

Mengatasi masalah yang dikemukakan di atas, terutama yang berkaitan representasi matematis, dan perangkat pembelajaran perlu dilakukan upaya pemilihan strategi maupun model pembelajaran yang tepat dan dapat menunjang keberhasilan pembelajaran. Salah satu pembelajaran yang dapat menjadi solusi dari permasalahan permasalahan diatas adalah dengan model pembelajaran melalui penemuan (Discovery Learning). Belajar melalui penemuan meliputi enam langkah berikut, yaitu: (1) stimulation (stimulasi/pemberian ragsangan, (2) problem statement (penyataan/identifikasi masalah), (3) data collection (pengumpulan data), (4) data processing (pengolahan data), (5) Verifikasi (Pembuktian) (6) generalization (menarik kesimpulan atau generalisasi).

Berdasarkan uraian keseluruhan latar belakang, peneliti tertarik untuk melakukan penelitian terkait dengan pembelajaran interaktif, model pembelajaran discovery learning, kemampuan representasi matematis siswa, dan yang berjudul "Pengembangan Pembelajaran Interaktif Berbasis Discovery Learning Untuk Meningkatkan Kemampuan Representasi Matematis Siswa MAN 1 Medan”.

\section{KAJIAN TEORITIS}

\section{Pembelajaran Interaktif Berbasis Penemuan (Discovery learning)}

Pembelajaran interaktif berbasis penemuan (Discovery learning) memiliki konsep belajar yang baik. Menurut Bruner tujuan strategi discovery learning memberikan kesempatan kepada muridnya untuk menjadi seorang problem solver, scientist, historin atau ahli matematik. Melalui kegiatan tersebut, peserta didik akan menguasai materi, mampu menerapkan, serta menemukan hal-hal yang bermanfaat bagi dirinya.

Bruner menjadikan pendapat Piaget sebagai dasar idenya, yaitu anak harus berperan aktif dalam belajar di kelas (Dalyono, 2005 : 41). Pelajaran dapat diajarkan secara efektif dalam bentuk intelektual sesuai tahap perkembangan anak, yaitu melalui cara yang bermakna dan makin meningkat ke arah yang abstrak.

1. Tahap Enaktive, anak melakukan aktivitasaktivitas dalam upaya memahami lingkungan, yaitu menggunakan pengetahuan motorik seperti sentuhan, gigitan.

2. Tahap Iconic, anak memahami objek melalui gambar dan visualisasi verbal.

3. Tahap Symbolic, anak memiliki ide atau gagasan abstrak yang dipengaruhi oleh kemampuannya dalam berbahasa dan logika.

Teori Bruner digunakan dalam penelitian ini karena berkaitan dengan discovery learning, dimana siswa aktif menemukan sendiri dan mempelajari konsep dengan bahasa mereka sendiri. Teori ini 
memiliki perspektif bahwa para siswa memproses infromasi dan pelajaran melalui upayanya mengorganisir, menyimpan, dan kemudian menemukan hubungan antara pengetahuan yang baru dengan pengetahuan yang telah ada. Teori ini menekankan pada bagaimana informasi diproses.

Menurut Hosnan (2014: 280) Belajar penemuan merupakan salah satu model pembelajaran yang digunakan dalam pendekatan kontruktivisme modern. Pada belajar penemuan siswa didorong untuk belajar sendiri yaitu melalui keterlibatan aktif dengan konsep-konsep dan prinsip-prinsip. Tugas guru adalah mendorong siswa agar mempunyai pengalaman dan melakukan eksperimen dengan memungkinkan mereka menemukan prinsip-prinsip atau konsep-konsep bagi diri mereka sendiri.

Tujuan Pembelajaran discovery learning, menurut Hosnan (2014: 284) yaitu:

a. Siswa memiliki kesempatan untuk terlibat aktif dalam pembelajaran.

b. Siswa belajar menemukan pola dalam situasi konkret maupun abstrak serta dapat meramalkan informasi tambahan yang diberikan oleh guru.

c. Siswa belajar merumuskan strategi tanya jawab yang tidak rancu dan menggunakan tanya jawab untuk memperoleh informasi yang bermanfaat.

d. Membantu siswa membentuk cara kerja bersamayang efektif, saling berbagi informasi, serta mendengar dan menggunakan ide-ide orang lain.

e. Ketrampilan-ketrampilan konsep-konsep dan prinsip-prinsip yang dipelajari lebih bermakna.

Ketrampilan yang dipelajari lebih mudah ditransfer untuk aktivitas baru dan diaplikasikan dalam situasi belajar yang baru.

\section{Kemampuan Representasi Matematis}

Salah satu kemampuan yang dituntut dalam pembelajaran matematika adalah kemampuan representasi matematis (NCTM, 2000). Menurut NCTM (2000), representasi merupakan translasi suatu masalah atau ide dalam bentuk baru, termasuk di dalamnya dari gambar atau model fisik ke dalam bentuk simbol, kata-kata atau kalimat. Dahlan (2011) menambahkan bahwa representasi merupakan dasar atau fondasi bagaimana seorang siswa dapat memahami dan menggunakan ide-ide matematika. Representasi berkaitan dengan dua hal, yaitu proses dan produk.

Hutagaol (2013: 91) meyebutkan representasi matematis yang dimunculkan oleh siswa merupakan ungkapan-ungkapan dari gagasan-gagasan atau ide matematika yang ditampilkan siswa dalam upayanya untuk memahami suatu konsep matematika ataupun dalam upayanya untuk mencari sesuatu solusi dari masalah yang sedang dihadapinya. Dengan demikian representasi dapat digunakan sebagai sarana bagi siswa untuk memahami konsep konsep tertentu maupun untuk mengomunikasikan ide-ide matematis guna menyelesaikan masalah.

Effendi (2012: 2) menyatakan kemampuan representasi matematis diperlukan siswa untuk menemukan dan membuat suatu alat atau cara berpikir dalam mengomunikasikan gagasan matematis dari yang sifatnya abstrak menuju konkret, sehingga lebih mudah untuk dipahami. Representasi memiliki peranan yang sangat penting dalam pembelajaran matematika dikarenakan siswa dapat mengembangkan dan memperdalam pemahaman akan konsep dan keterkaitan antar konsep matematika yang mereka miliki melalui membuat, membandingkan, dan menggunakan representasi. Bukan hanya baik untuk pemahaman siswa, representasi juga membantu siswa dalam mengkomunikasikan pemikiran mereka.

Kemampuan representasi matematis siswa dapat diukur melalui beberapa indikator kemampuan representasi matematis. Menurut Amelia (2013: 20), indikator representasi matematis siswa adalah, (1) representasi visual (diagram, tabel atau grafik, dan gambar), (2) persamaan atau ekspresi matematis, dan (3) kata-kata atau teks tertulis.

\section{METODE PENELITIAN}

Jenis penelitian ini adalah Penelitian Pengembangan (Reseach and Development), dengan menggunakan model pengembangan perangkat pembelajaran Thiagarajan, Semmel dan Semmel, yaitu model 4-D (define, design, develop, dan disseminate). Dalam penelitian ini berpusat untuk mengembangkan pembelajaran interaktif melalui model pembelajaran discovery learning pada materi trigonometri.

Subjek dalam penelitian ini adalah siswa kelas $\mathrm{X}$ MAN 1 Medan tahun ajaran 2020/2021 pada kelas X IIS 1 dan X IIS 2, sedangkan objek dalam penelitian ini adalah pembelajaran interaktif melalui model pembelajaran discovery learning pada materi trigonometri untuk meningkatkan kemampuan Representasi Matematis (TKRM) siswa. Perangkat pembelajaran yang akan dihasilkan adalah rencana pelaksanaan pembelajaran (RPP), Buku Siswa (BS), Buku Guru (BG), Lembar Aktivitas Siswa (LAS), tes kemampuan representasi matematis.

Sebelum postes kemampuan representasi matematis digunakan pada uji coba I dan uji coba II, instrumen tes kemampuan representasi matematis terlebih dahulu diujicobakan di luar kelas sampel, kemudian hasil uji coba tersebut dianalisis validitas dan reliabilitasnya. Cara menganalisis kepraktisan perangkat pembelajaran yaitu dengan memberikan perangkat pembelajaran interaktif kepada validator untuk divalidasi. Keefektifan perangkat pembelajaran terkait kemampuan representasi matematis ditentukan berdasarkan pencapaian ketuntasan belajar siswa secara klasikal. Dan data yang diperoleh dari hasil tes dianalisis untuk mengetahui peningkatan kemampuan representasi matematis siswa. Skor yang diperoleh siswa sebelum dan setelah menggunakan perangkat pembelajaran yang telah dikembangkan dianalisis dengan cara membandingkan skor siswa yang diperoleh dari hasil tes siswa sebelum dan setelah diberi perlakuan.

Pengembangan Pembelajaran Interaktif Berbasis Discovery Learning untuk Meningkatkan Kemampuan Representasi Matematis Siswa MAN 1 Medan 


\section{HASIL PENELITIAN \\ Kevalidan Pembelajaran Interaktif yang Dikembangkan dengan Model Discovery Learning}

Dapat disimpulkan bahwa hasil validasi untuk masing-masing komponen perangkat pembelajaran interaktif melalui model discovery learning yang dikembangkan berada pada kategori "valid" dengan nilai rata-rata masing-masing komponen yaitu: Rencana Pelaksanaan Pembelajaran (4,33); Buku Guru (4,24); Buku Siswa $(4,31)$ dan LKPD $(4,33)$. Tetapi walaupun komponen perangkat pembelajaran yang dikembangkan telah memenuhi kriteria kevalidan, ada beberapa hal yang harus diperbaiki sesuai dengan catatan-catatan yang diberikan oleh tim ahli meliputi penggunaan bahasa, penulisan atau pengetikan dan tampilan gambar yang harus sesuai dengan kondisi materi. Sehingga berdasarkan hasil catatan dari para ahli bahwa perangkat pembelajaran ini telah memenuhi kriteria kevalidan dengan kategori "valid" dengan catatan sedikit revisi atau tanpa revisi.

\section{Kepraktisan Pembelajaran Interaktif yang Dikembangkan dengan Model Discovery learning \\ Dari hasil validasi para ahli dan hasil wawancara,} dapat disimpulkan bahwa pembelajaran interaktif melalui model discovery learning yang telah dikembangkan ini "praktis" untuk digunakan di dalam pembelajaran.

\section{Keefektifan Pembelajaran Interaktif yang Dikembangkan dengan Model Discovery Learning}

Berdasarkan hasil uji coba I dan uji coba II, pembelajaran interaktif melalui model discovery learning yang dikembangkan telah memenuhi kategori efektif ditinjau dari: (1) ketuntasan belajar siswa secara klasikal; (2) ketercapaian tujuan pembelajaran; (3) respon siswa dan (4) waktu pembelajaran. Berikut ini akan disajikan pembahasan untuk masing-masing indikator dalam mengukur keefektifan pembelajaran interaktif yang dikembangkan dengan model discovery learning. Selanjutnya, hasil ketuntasan secara klasikal kemampuan representasi matematis siswa pada uji coba I dapat dilihat pada tabel 1.

Tabel 1. Tingkat Ketuntasan Klasikal Kemampuan Representasi Matematis pada Uji Coba I

\begin{tabular}{|c|c|c|c|c|}
\hline \multirow[b]{2}{*}{ Kategori } & Pretest & Persentase & Posttest & Persentase \\
\hline & $\begin{array}{c}\text { Jumlah } \\
\text { Siswa }\end{array}$ & $\begin{array}{c}\text { Ketuntasan } \\
\text { Klasikal }\end{array}$ & $\begin{array}{l}\text { Jumlah } \\
\text { Siswa }\end{array}$ & $\begin{array}{c}\text { Ketuntasan } \\
\text { Klasikal }\end{array}$ \\
\hline Tuntas & 17 & $53,13 \%$ & 22 & $68,75 \%$ \\
\hline Tidak Tuntas & 15 & $46,87 \%$ & 10 & $31,25 \%$ \\
\hline Jumlah & 32 & $100 \%$ & 32 & $100 \%$ \\
\hline
\end{tabular}

Berdasarkan data pada tabel 1. di atas, terlihat bahwa ketuntasan klasikal dari hasil kemampuan representasi matematis siswa pada pretest uji coba I sebesar $53,13 \%$ sedangkan pada posttest uji coba I sebesar $68,75 \%$.

Selanjutnya, hasil ketuntasan belajar siswa secara klasikal untuk kemampuan representasi matematis siswa pada uji coba II dapat dilihat pada tabel 2. di bawah.

Tabel 2. Tingkat Ketuntasan Klasikal Kemampuan Representasi Matematis pada Uji Coba II

\begin{tabular}{|c|c|c|c|c|}
\hline \multirow[b]{2}{*}{ Kategori } & Pretest & Persentase & Posttest & Persentase \\
\hline & $\begin{array}{c}\text { Jumlah } \\
\text { Siswa }\end{array}$ & $\begin{array}{c}\text { Ketuntasan } \\
\text { Klasikal }\end{array}$ & $\begin{array}{l}\text { Jumlah } \\
\text { Siswa }\end{array}$ & $\begin{array}{c}\text { Ketuntasan } \\
\text { Klasikal }\end{array}$ \\
\hline Tuntas & 21 & $65,63 \%$ & 28 & $87,50 \%$ \\
\hline Tidak Tuntas & 11 & $34,37 \%$ & 4 & $12,50 \%$ \\
\hline Jumlah & 32 & $100 \%$ & 32 & $100 \%$ \\
\hline
\end{tabular}

Berdasarkan data pada tabel 2. di atas terlihat bahwa ketuntasan klasikal dari hasil kemampuan representasi matematis siswa pada pretest uji coba I sebesar $65,63 \%$ sedangkan pada posttest uji coba I sebesar $87,50 \%$. Kemudian, Deskripsi hasil kemampuan siswa pada uji coba I ditunjukkan pada tabel 3 .

Tabel 3. Deskripsi Hasil Kemampuan Siswa Uji Coba I dan Uji Coba II

\begin{tabular}{|c|c|c|c|c|}
\hline \multirow[b]{2}{*}{ Ket } & \multicolumn{2}{|c|}{ Uji Coba I } & \multicolumn{2}{|c|}{ Uji Coba II } \\
\hline & $\begin{array}{c}\text { Pretest } \\
\text { Kemampuan } \\
\text { Matematis }\end{array}$ & $\begin{array}{c}\text { Posttest } \\
\text { Kemampuan } \\
\text { Matematis }\end{array}$ & $\begin{array}{c}\text { Pretest } \\
\text { Kemampuan } \\
\text { Matematis }\end{array}$ & $\begin{array}{c}\text { Posttest } \\
\text { Kemampuan } \\
\text { Matematis }\end{array}$ \\
\hline $\begin{array}{l}\text { Nilai } \\
\text { Tertinggi }\end{array}$ & 72,22 & 86,11 & 83,33 & 94,44 \\
\hline $\begin{array}{l}\text { Nilai } \\
\text { Terendah }\end{array}$ & 41,67 & 52,78 & 52,78 & 63,89 \\
\hline Rata-rata & 61,99 & 73,09 & 71,53 & 81,34 \\
\hline
\end{tabular}

kemampuabel 3., menunjukkan bahwa rata-rata adalah sebesar 61,99 dan pada hasil posttest adalah sebesar 73,09. Ketercapaian tujuan pembelajaran posttest kemampuan representasi matematis pada uji coba I dan uji coba II sudah tercapai. Hasil pencapaian waktu pembelajaran pada uji coba I dan uji coba II adalah tiga kali pertemuan atau $3 \times 40$ menit, jika dibandingkan dengan pembelajaran konvensional yang dilakukan selama ini, tidak terdapat perbedaan antara pencapaian waktu pembelajaran interaktif dengan model discovery learning pada uji coba I dengan pencapaian waktu pembelajaran konvensional. Dengan demikian pencapaian waktu pembelajaran interaktif dengan model discovery learning pada uji coba I sama dengan pembelajaran biasa yaitu tiga kali pertemuan atau 6 x 40 menit. Hal ini sesuai dengan kriteria waktu pembelajaran, yaitu pencapaian waktu pembelajaran minimal sama dengan pembelajaran konvensional, dengan demikian pencapaian waktu pembelajaran uji coba I sudah tercapai.

Peningkatan Kemampuan Representasi Matematis Siswa dengan Menggunakan Pengembangan Perangkat Pembelajaran dengan Model Discovery Learning. Berdasarkan hasil analisis posttest kemampuan representasi matematis siswa pada uji coba I dan uji coba II menunjukkan 
bahwa kemampuan representasi matematis siswa meningkat. Peningkatan kemampuan representasi matematis siswa ini terlihat dari rata-rata hasil posttest kemampuan representasi matematis yang diperoleh siswa pada uji coba I sebesar 68,75\% meningkat menjadi $87,50 \%$ pada uji coba II. Dengan demikian, terjadi peningkatan kemampuan representasi matematis siswa sebesar $18,75 \%$. Hal ini menunjukkan bahwa penggunaan perangkat pembelajaran berbasis discovery learning yang dikembangkan berdampak pada peningkatan kemampuan representasi matematis siswa.

Peningkatan kemampuan representasi matematis siswa dikarenakan proses pembelajaran interaktif berbasis discovery learning yang dikembangkandiawali dengan masalah, sehingga siswa dapat menggunakan pengalaman yang dimiliki sebelumnya dalam memahami dan menyelesaikan persoalan matematika. Masalah dirancang agar proses pembelajaran lebih bermakna, sehingga dapat dipahami bahwa masalah yang diberikan dapat dijadikan sebagai titik awal dalam mengembangkan kemampuan representasi matematis siswa. Selanjutnya diskusi yang dilakukan oleh siswa merupakan jembatan saling membantu antara siswa dalam memahami masalah. Hal ini sejalan dengan teori Ausubel (Trianto, 2011) yaitu belajar bermakna merupakan suatu proses dikaitkannya informasi baru pada konsep-konsep relevan yang terdapat dalam struktur kognitif seseorang. Dalam belajar bermakna proses pembelajaran dimulai dari masalah dan terjadi proses pengkonstruksian informasi. Dengan kata lain, suatu pengetahuan akan menjadi bermakna bagi siswa jika proses belajar melibatkan masalah atau dilaksanakan dengan model discovery learning.

\section{KESIMPULAN}

1. Pembelajaran interaktif berbasis Discovery learning yang telah dikembangkan di MAN 1 Medan sudah memenuhi kategori valid, praktis dan efektif.

2. Kemampuan representasi matematis siswa MAN 1 Medan dengan pembelajaran interaktif berbasis Discovery learning meningkat, ditinjau dari: (1) ketuntasan klasikal posttest uji coba I sebesar $68,75 \%$ meningkat menjadi $87,50 \%$ pada uji coba II; dan (2) $N$-Gain uji coba I sebesar 0,21 pada kategori rendah meningkat menjadi 0,37 pada kategori sedang pada uji coba II.

3. Kemampuan siswa MAN 1 Medan dengan pembelajaran interaktif berbasis Discovery learning meningkat, ditinjau dari: (1) ketuntasan klasikal posttest uji coba I sebesar 68,75\% meningkat menjadi $87,50 \%$ pada uji coba II; dan (2) $\mathrm{N}$-Gain uji coba I sebesar 0,25 pada kategori rendah meningkat menjadi 0,31 pada kategori sedang pada uji coba II.

\section{UCAPAN TERIMA KASIH}

Pada kesempatan ini penulis mengucapkan terima kasih kepada Prof. Dr. Bornok Sinaga, M.Pd. selaku Direktur Pascasarjana UNIMED dan pihak sekolah MAN 1 Medan yang telah memfasilitasi penulis, sehingga penelitian ini dapat diselesaikan sebagaimana yang diharapkan.

\section{DAFTAR PUSTAKA}

Adnani, D. M. 2015. Pengembangan Perangkat Pembelajaran Berbasis Masalah untuk Meningkatkan Kemampuan Berpikir Kritis Matematis dan Siswa MTs Swasta IRA Medan. Tesis PPs: UNIMED.

Ali, M. 2004 Guru dalam Proses Belajar Mengajar. Bandung: Sinar Baru Algesindo.

Amelia, A. 2013. Peningkatan Kemampuan Representasi Matematis Siswa SMP Melalui Penerapan Pendekatan Kognitif. Universitas Pendidikan Indonesia: Bandung.

Bouchey, H.A., dan Harter, S. 2005. Reflected Appraisals, Academic Self Perceptions, and Math/Science Performance During Early Adolescence. Journal Pesychology No 97 Vol 4.

Dalyono. 2005. Psikologi Pendidikan. Jakarta : Rineka Cipta.

Effendi, L. A. 2012. Pembelajaran Matematika dengan Metode Penemuan Terbimbing untuk Meningkatkan Kemampuan Representasi dan Pemecahan Masalah Matematis Siswa SMP. LPPM UPI. Jurnal Penelitian Pendidikan Vol 13 No. 2 ISSN 1412-565X.

Hosnan. 2014. Pendekatan Saintifik dan Kontekstual dalam Pembelajaran Abad 21. Jakarta : Galian Indonesia.

Hutagaol, K. 2013. Pembelajaran Kontekstual untuk Meningkatkan Kemampuan Representasi Matematis Siswa SMP. Infinity: Jurnal Ilmiah Program Studi Matematika STKIP Siliwangi Volume 2 Nomor 1 Bandung.

Mustangin. 2015. Representasi Konsep dan Peranannya dalam Pembelajaran Matematika di Sekolah. Jurnal Pendidikan matematika , 1(1):15-21.

NCTM. 2000. Principles and Evaluation Standards for school Mathematics. Reston, VA: NCTM.

Rahmawati, E., dan Suhendri, H. 2016. Pengembangan Desain Pembelajaran Matematika Siswa Sekolah Dasar Kelas 6. Jakarta: Jurnal Formatif, 6(3): 184-196.

Sabirin, M. 2014. Representasi Dalam Pembelajaran Matematika. JPM IAIN Antasari. Volume 01 Nomor 02 Januari -Juni 2014.

Schunk, D. H. 1995. Motivation and Performance. Journal of Applied Sport Psychology.

Somakim. 2010. Peningkatan Kemampuan Berpikir Kritis dan Matematik Siswa Sekolah Menengah Pertama dengan Penggunaan Pendekatan Mateatika Realistik. Disertasi Tidak Dipublikasikan. Bandung: Program Pascasarjana UPI Bandung.

Syafri, F. S. 2017. Kemampuan Representasi Matematis dan Kemampuan Pembuktian

Pengembangan Pembelajaran Interaktif Berbasis Discovery Learning untuk Meningkatkan Kemampuan Representasi Matematis Siswa MAN 1 
Vol.14, No. 1, Juni 2021

Matematika. Jurnal Edumath, Volume 3 Nomor

1, Januari 2017, Hlm. 49 -55.

Trianto. 2011. Mendesain Model Pembelajaran Inovatif-Progresif. Penerbit Kencana Prenada Media Group, Jakarta.

Wahab, R. 2016. Psikologi Belajar. Jakarta: PT RajaGrafindo Persada.

Zazkis, R., dan Liljedahl, P. 2004. Understanding Primes: The Role of Representation. Journal for Research in Mathematics Education 2004. Vol.35, No. 3, 164-186. 